\title{
Why They Connected: A Theoretical Analysis on the Cause of Interfirm Network Formation
}

\author{
Zhengqun Zhan, Xuejun Deng \\ School of Economics and Commerce, South China University of Technology, Guangzhou, China \\ Email: aprilzhan@hotmail.com
}

Received July 2014

\begin{abstract}
Empirical studies have demonstrated that the motivations which lead a firm to construct networks are diversified, and are usually a synthetic result from different type motivations. We found that firms construct their networks for many different reasons, including economic factors (reducing costs, obtaining scarce resources, improving market competitiveness, etc.), and social factors (as when a new or small-scaled firm joins a well-established network to improve their image and acquire social recognition or legitimacy).The construction of an interfirm network is driven firstly by resource reliance. Secondly, economic benefits and improvement in market position brought about by such networks have driven many firms to construct interfirm networks. Finally, the social restraints arise mainly from the pressures imposed by social norms.
\end{abstract}

\section{Keywords}

Interfirm Network, Resource Reliance, Economic Benefits, Social Norms

\section{Introduction}

Firms have increasingly moved productive activities from insider to outsider through building interfirm network. With regard to the question of why firms build interfirm networks, different schools of thought have provided numerous different opinions and theories, which are mainly classified into three types: resource-based, transaction cost and institutional school. We will discuss the main points of these schools in the following context and then we draw an integrated framework to interpret the cause of interfirm network formation.

\section{Open System, Resources Interlocking and Interfirm Network}

The resource-based theory regards an organization as a member of a relatively stable alliance [1]. This theory holds that firms build interfirm networks because of the interlocking resources between them.

Adopting the organization view of an open system, the resource-based theory also considers that an organization is an open system, which is influenced not only by its own resources and abilities, but also by external environments such as a social institutional environment or an industrial environment. As pointed out by Buckley, 
an open system not only exists because of its mutual exchange relationship with the external environment but also because of the key role played by such a relationship in system change [2]. Firms closely link themselves to other organizations, in order to obtain new technology and the knowledge they require to extend to new markets. Establishing a relationship between a firm and an organization can be impacted by many factors. This is a result from contingency [3].

The resource-based theory views an organization as a member of a relatively stable alliance. The stability may come from inside the firm in the form of shareholders, managers or employees, or from outside of the firm in the form of customers, suppliers, competitors and the government. Every alliance imposes different interests' requirements upon the organization. First, the interested parties may possess some means (for example, holding stock rights) through which they can influence a firm's behavior. Secondly, the interested parties may be able to control certain resources required by firms to operate successfully. These resources could include, for instance, managers in key positions. Thirdly, the interested parties may be able to control channels through which the firm utilizes their resources, such as a labor union. Finally, the interested parties may be able to supervise the ownership of key resources, such as the allocation by the government of mining rights to firms dealing in forest products.

Such a theory interprets the power distribution inside an organization through the dependency of the organization upon the environment. An organization is an open system, with its structure, function and fate dominated to an extremely significant extent by the environment. In other words, organizations which participate in the exchanges of the anticipated environment must do so because of their failure to be self-sufficient [4]-[6]. Instead, they should consider the critical problem of how to survive, the key to which lies precisely in properly managing their reliance on the environment. Organizations depend on the environment mainly in the following three forms: 1) Raw materials, including funds and human resources; 2) information, and 3) social and political support, or legitimacy. The degree of their dependency on the environment is determined by the scarcity of the resources needed and the organization's ability to obtain these resources. Correspondingly, those allies who can help the organization acquire such resources must also receive from the organization the necessary power to do so.

Organizations frequently encounter uncertainty, for which they have to depend on external environment information to deal with any such uncertainty. The uncertainty facing the organizations is derived from the limited rationality in the humans who are estimating all of the environmental variables and the complicated relationships among organizations. It is widely believed among scholars that the collective intelligence of individuals would be superior to that of independent individuals in information processing. Put another way, organizations try to enhance their processing ability by combining together the cognitive abilities of many individuals. Nevertheless, the ability of organizations to estimate the fluctuations of both the internal and external environments is still subject to their own individuals' abilities.

The resource-based theory allows for the limitations in an organization's knowledge base. No organization can discover all potential solutions to a single problem and then determine the possible outcome from employing those solutions and anticipating the influence of the intentions and actions of other organizations reacting to its own behavior. Besides, due to the reciprocal causation between the labor division and specialization among organizations, the level of uncertainty has intensified. Organizations depend on the information environment, and such dependency grows as the environment changes and technology improves. Organizations are also the consumers of environmental resources and are a part of the larger social system which subordinates them under the external environment. Given that organizations obtain the resources they need from the environment, they must make judgments with respect to their own position and operation. The organizations need to gain social and political support from the environment in which they survive, so as to ensure the continuity of supply of resources from that environment. Therefore, determining how to effectively manage or govern their external networks is of great importance to firms.

As mentioned earlier, the key to an organization's survival is the proper management of the environment upon which it depends. In such circumstances, those participants or subsystems with the resources helpful to the organization will seek corresponding power within that organization. The structural relationship between an organization and its participants may be simplified into brief exchange of logic. An organization is a fixed, formal place of market exchange, where the organization and its participants engage in power exchanging for resources. The resource-based theory claims that the dependency of an organization on the external environment determines its internal structure, and particularly the power allocation within the organization. The degree of such influence is further determined by the following three factors: 1) the importance of resources or services in solving 
the problems faced by the organization, such as interdependency and uncertainty; 2) the ability of an organization to substitute resources or services, and 3) the ability and extent of the members to utilize and apply the resources and services provided. Supplying only those resources and services needed cannot solve all the problems facing the organization, because it is the power attached to those participants who are able to control and apply these resources and services at critical moments that maximizes the benefits to the organization

\section{Cost Saving and Interfirm Network}

Focusing on the economic advantages of alliances between firms, scholars of the transaction-cost economics (TCE) school hold that networks are a mix of purely bi-directional interfirm cooperation agreements. They maintain that firms decide to construct networks and engage in network governance based on cost comparisons between production or outsourcing patterns.

TCE studies have provided interpretations from the following two aspects: 1) What motivates firms to create bi-directional ties? 2) What is the governance mechanism used to maintain the stability of such ties? In studies of the TCE school, it is proposed that any suggestion about participating in cooperation may be decomposed into two decisions.

The first of these is the make-or-buy decision. In the context of cooperation among firms, the purchasing decision (cooperating with other firms) is based on the possibility of producing at a lower governance cost, while the production decision (choosing not to cooperate with other firms) is based on lower organizational costs. Thus, an inter-organization association will only be formed if such an alliance can help bring down transaction costs (a combination of governance and organization costs)

Once the decision has been made to build such ties, the second decision would involve the selection of an appropriate governance mechanism or contract structure which reflects the economic motivation for the proposed network participation. The analytical framework of a transaction cost has pointed out two dimensions of governance structure design. First, the structure must be an equity-based governing structure, which can reduce the opportunistic inclinations of partners, demonstrated by the fact that joint ventures are widely welcomed when the opportunistic inclinations rise. Secondly, such interfirm associations must be able to reduce information asymmetry as a communication channel. Failure to do so is the primary cause which leads to alliance failures. In particular, when the governance structure of transactions can be explicitly coded into written text, such that contract drafting may become more economical and thus more feasible, the parties will reach a non-equity partnership agreement, such as full permission, etc. However, if an exchange involves large quantities of explicit knowledge, contract drafting will become economically prohibitive, thus leaving cooperators with no option except to select a self-governing structure, such as an equity-based partnership.

The TCE theory analysis has been criticized by many scholars for its over-simplicity, as it only touches upon the cost factors concerned. For example, based on longitudinal studies of American firms, Gomes-Casseres (1996) believes that interfirm alliances are promoted by the action of some alliances which searching for competitors among major firms. This is done to strengthen the competitiveness against rival firms. Any industry has only a limited number of potential partners. Firms tend to buy out their potential competitors, in order to ally with them as much as possible. Such alliances reduce the options left to the remaining major competitors. As soon as an industry leader makes a clear action to buy out another firm, such a strategic maneuver will intensify the competition between alliance partners and further enhance full-scale interfirm alliances in the industry [7] [8].

\section{Learning Ability, Legitimacy and Interfirm Network}

While TCE school scholars emphasize the economic motivation behind the construction of interfirm networks, the institutional theory argues that the advantages brought about by such interfirm alliances or networks are not limited to economic benefits. Based on this theory, when an interfirm network is built in the form of multiple interfirm ties, the firms in such a network will enjoy benefits from at least three aspects [9] [10].

The first benefits that the network provides a rapid transmission channel through which organizations may learn externally implicit knowledge. As pointed out by Kogut, a network is a facilitator for the rapid transmission of self-contained information [11]. Based on above definition, the form of a network has facilitated a new synthesis of knowledge, which differs completely from the original information preserved on various nodes in terms of quality [9]. 
The second benefit of an interfirm network is the acquisition of legitimacy [10]. In other words, the form or behavior of a firm or organization complies with the law, conventions and social customs, and is recognized by other firms, organizations and individuals [12] [13]. Based on the institutional theory, building a tie with an organization which having an excellent reputation or a well-established industry network will produce significant economic benefits (i.e. survival rate and market capitalization) for a firm which has not yet been widely acknowledged within the industry. An organization which relatively low status may acquire its legitimacy through cooperation with a firm holding a higher status. What is also worth pointing out is that legitimacy itself is also included at network level, and that the existence of an interfirm network cannot be proven to be appropriate until it is able to continuously and steadily obtain its legitimacy from both its internal members and external equity owners.

The economic contribution of an interfirm coordination is the third benefit of an interfirm network. Contrary to the economic benefits discussed by the TCE school, the institutional school believes such benefits are derived from smooth inter-network communications between organization members, rather than a reliance on market mechanisms to improve the quality of the network's organization form. Good inter-network communications help firms improve the quality of their goods and services and also help them respond in a timely manner to intensive environment changes [14]-[16].

The institutional theory also maintains that organizations exist in a certain unstable state, as they operate in a social system which is subject to the rules of entropy [17]. Thus, facing infinite changes, organizational restructuring continuously occurs, simply to maintain their integrity [18] [19]. On the other hand, an organization can be deemed to be currently in a stable state, just because it is closely linked to the social systems in which it is located. These links grant the organization a high level of stability. Given that the stability of any social system is dominated by the consistency of that system, organizational restructuring is an action aimed at actually reducing such consistency and providing the opportunity to create a social order which is friendlier to the organization itself. If we apply the same motivation as the reason for the organizational restructuring of interfirm networks, it means that the networks built among firms will undoubtedly be in an unstable state. In order to maintain the integrity of the networks where firms locate, they will inevitably select and/or eliminate their partners, thus generating a dynamic network governance process.

\section{Discussion and Conclusion}

Empirical studies have demonstrated that the motivations which lead firm to construct networks are diversified, and are usually synthetic result from the above three types of motivations.

First, the dependency on external resources will ultimately determine that a firm must ally with other firms or organizations. Due to the division of labor and market specialization, a firm is unlikely to have access to all the resources it needs. Therefore, allying with other firms is a necessity. For example, from the perspective of a value chain, a firm is always in a network which is comprised of suppliers, consumers and competitors, thus forming an industry value chain-based knowledge chain. The firm also receives support from many professional service suppliers. For example, firms, receive financial support from financial institutions, and they get policy support from the government or industry institutions. The external and internal networks act as enablers of knowledge acquisition and appropriation [20] [21]. Therefore, the construction of an interfirm network is driven firstly by resource reliance.

Secondly, economic benefits and an improvement in market position brought about by such networks have driven many firms to construct interfirm networks. From their perspective, when deciding whether or not and how to obtain resources from the external environment, a firm has to weigh up both the costs and benefits. The firms, however, are also restrained by market, social and other factors. The market restraints mainly come in the form of the intensification of competition within the marketplace. If allying with another firm will give greater competitive advantages to a firm, they may construct an expensive network without even considering the costs [22]. The social restraints arise mainly from the pressures imposed by social norms. For example, many firms have engaged in philanthropy and formed local labor unions. Newly-founded firms are more willing to join hands with firms which enjoy an excellent reputation, in order to elevate the legitimacy of the newer firm in the eyes of society.

In conclusion, firms construct their networks for many different reasons, including economic factors (reducing costs, obtaining scarce resources, improving market competitiveness, etc.), and social factors (as when a new 
or small-scaled firm joins a well-established network to improve their image and acquire social recognition or legitimacy). In practice, the development of interfirm network relationships has provided broad horizons to scholars in terms of research. For example, will different motivations lead to different strategies and effect the network construction of different firms? In addition, at various developmental stages, firms usually face different environments and strategic interests. Such changes can lead a firm to determine that building an interfirm network will be a dynamic adjustment process which will increase the benefits firms obtain from the formed networks. Put another way, the subject of interfirm networks touches upon such problems as whether or not firms will adjust their objective of constructing a network, given the changes in time and the environment, as well as how the firms will make adjustments in response to those changes.

\section{Acknowledgements}

This research was financially supported by the Fundamental Research Funds for the Central Universities (program ID: x2jmD2118210).

\section{References}

[1] Pfeffer, J. and Salancik, G.R. (1978) The External Control of Organizations: A Resource Dependence Perspective. Harper \& Row, New York.

[2] Buckley, P.J. and Niron, H. (2004) A Global System View of Firm Boundaries. Journal of International Business Studies, 35, 33-45. http://dx.doi.org/10.1057/palgrave.jibs.8400059

[3] Oliver, C. (1990) Determinants of Interorganizational Relationships: Integration and Future Directions. Academy of Management Review, 15, 241-265.

[4] Ulrich, D. and Barney, J.B. (1984) Perspectives in Organizations: Resource Dependence, Efficiency, and Population. Academy of Management Review, 9, 471-81.

[5] Dyer, J.H. and Singh, H. (1998) The Relational View: Cooperative Strategy and Sources of Interorganizational Competitive Advantage. Academy of Management the Academy of Management Review, 23, 660-679.

[6] Kenny, B. and Fahy, J. (2011) Network Resources and International Performance of High Tech SMEs. Journal of Small Business and Enterprise Development, 18, 529-555. http://dx.doi.org/10.1108/14626001111155691

[7] Gomes-Casseres, B. (1996) The Alliance Revolution: The New Shape of Business Rivalry. Harvard University Press, Cambridge.

[8] Gomes-Casseres, B., Hagedoorn, J. and Jaffe, A.B. (2006) Do Alliances Promote Knowledge Flows? Journal of Financial Economics, 80, 5. http://dx.doi.org/10.1016/j.jfineco.2004.08.011

[9] Podolny, J.M. (2001) Networks as the Pipes and Prisms of the Market. American Journal of Sociology, 107, 33-60. http://dx.doi.org/10.1086/323038

[10] Podolny, J.M. and Page, K.L. (1998) Network Forms of Organization. Annual Review of Sociology, 24, 57-76. http://dx.doi.org/10.1146/annurev.soc.24.1.57

[11] Kogut, B. (2000) The Network as Knowledge: Generative Rules and the Emergence of Structure. Strategic Management Journal, 21, 405-425. http://dx.doi.org/10.1002/(SICI)1097-0266(200003)21:3<405::AID-SMJ103>3.0.CO;2-5

[12] Zhou, X. (1993) The Dynamics of Organizational Rules. The American Journal of Sociology, 98, 1134-1166. http://dx.doi.org/10.1086/230141

[13] Zhou, X., Li, Q., Zhao, W. and Cai, H. (2003) Embeddedness and Contractual Relationships in China's Transitional Economy. American Sociological Review, 68, 75-102. http://dx.doi.org/10.2307/3088903

[14] Uzzi, B. (1996) The Sources and Consequences of Embeddedness for the Economic Performance of Organizations: The Network Effect. American Sociological Review, 61, 674-698. http://dx.doi.org/10.2307/2096399

[15] Uzzi, B. and Gillespie, J.J. (2002) Knowledge Spillover in Corporate Financing Networks: Embeddedness and the Firm's Debt Performance. Strategic Management Journal, 23, 595-618. http://dx.doi.org/10.1002/smj.241

[16] Xu, G., Liu, X., Zhou, Y. and Su, J. (2012) Effects of Relational Embeddedness on Technological Innovation. Chinese Management Studies, 6, 108-123. http://dx.doi.org/10.1108/17506141211213816

[17] Zucker, L.G. (1987) Institutional Theories of Organization. Annual Review of Sociology, 13, 443-464. http://dx.doi.org/10.1146/annurev.so.13.080187.002303

[18] DiMaggio, P. (1988) Interest and Agent in Institutional Theory. Institutional Patterns and Organizations, Cambridge University Press, 3-22. 
[19] DiMaggio, P. and Powell, W. (1984) The Iron Cage Revisited: Institutional Isomorphism and Collective Rationality. American Sociological Review, 42, 726-768.

[20] Bohorquez, L.V.W. and Esteves, J. (2013) Acquiring External Knowledge to Avoid Wheel Re-Invention. Journal of Knowledge Management, 17, 87-105. http://dx.doi.org/10.1108/13673271311300787

[21] Parker, H. (2012) Knowledge Acquisition and Leakage in Inter-Firm Relationships Involving New Technology-Based Firms. Management Decision, 50, 1618-1633. http://dx.doi.org/10.1108/00251741211266714

[22] Lechner, C. and Dowling, M. (2003) Firm Networks: External relationships as Sources for the Growth and Competitiveness of Enterpreneurial Firms. Enterpreneurship \& Regional Development, 1-26. 